abdomen was tympanitic and high-pitched bowel sounds were heard. The bowels had not moved for a week, but the rectum was empty. Sigmoidoscopy was not contributory. General examination confirmed the signs of myxoedema. $X$-ray confirmed the diagnosis of volvulus, and a Paul-Miculicz resection of sigmoid colon was carried out. The volvulus was very large with two turns at the base, and appeated to be chronic. The $68-\mathrm{cm}$. resected length of colon attained a maximal luminal diameter of $12 \mathrm{~cm}$., and histologically the bowel wall showed flattened colonic mucosa and distended veins.

Further investigations were as follows : P.B.I. $1.1 \mu$ g. $/ 100 \mathrm{ml}$. ; radioiodine tracer studies, including T.S.H. stimulation, confirmed primary hypothyroidism; and antithyroid antibodies present.

L-thyroxine was cautiously administered, and four months after admission the patient is euthyroid and asymptomatic. The colostomy was closed at a second operation.

Neither hypothyroidism nor volvulus is uncommon, and their appearance in the same patient may be coincidental. However, if the diagnosis of hypothyroidism were considered more often in patients with chronic constipation and abdominal distension a few potential cases of intestinal obstruction could be treated prophylactically-with thyroxine. -We are, etc.,

Peter Cole. James C. Petrie.

Aberdeen. P. D. BEW SHER.

\section{Stool Collection}

SIR,-The direct microscopical examination of stools for intestinal protozoa should be carried out on a freshly passed specimen which has not had time to cool. Ideally the specimen should be passed at the laboratory, but most laboratories are equipped only with normal W.C. pans. The equipment illustrated has proved convenient and is not difficult to make locally.

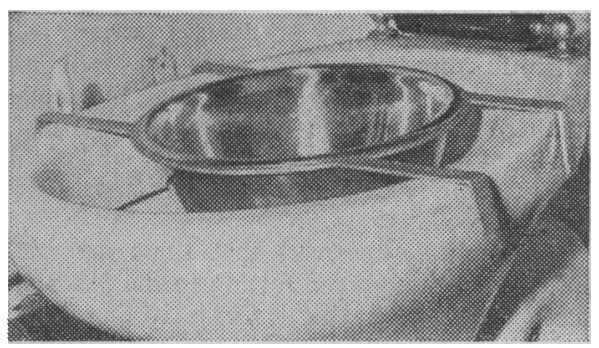

A strip metal frame has a circular hole to accept a standard 8 in. $(20 \mathrm{~cm}$.) stainless steel bowl and four hooked supports. This is placed across the W.C. pan as shown; the support does not interfere with the normal lowering of the seat.-I am, etc.,

R.A.F. Institute of Pathology and Tropical

$$
\text { R. MORTIMER. }
$$

Halton, Bucks.

\section{Drinking Drivers}

SIR,-A further discrepancy in the breathalyser test is becoming apparent. This is due to the considerable difficulty in deciding whether a driver is above or below the breathalyser dead-line. Some feel that any yellow crystals below the line mean safety, while others think that any green crystals above the line mean danger. The wise duty officer in the police station will obviously ask for blood tests when he is in doubt. This means that the efficiency of a police division may well be indicated by the percentage of blood tests which is under $80 \mathrm{mg} . / 100 \mathrm{ml}$.

The hard practical lesson which I have learned through sleepless nights is that the colour end-point of the breathalyser is not satisfactory. - I am, etc.,

$$
\begin{aligned}
& \text { J. H. HENDERSON, } \\
& \text { "A " Division. Police Surgeon, } \\
& \text { Renfrew and Bute Constabulary. }
\end{aligned}
$$

\section{Greenock,} Renfrewshire.

\section{Management of Unconscious Poisoned Patients}

SIR,-Dr. E. G. McQueen (19 July, p. 177) states that " short- and medium-acting barbiturates are markedly longer acting than phenobarbitone in gross overdosage" (our italics). We would be interested to examine his supporting evidence, as our experience differs markedly. The following Table shows the duration of coma after admission to hos-

\begin{tabular}{|c|c|c|c|}
\hline Barbiturate Type & $\begin{array}{l}\text { Grade } \\
\text { of } \\
\text { Coma }\end{array}$ & $\begin{array}{c}\text { Number } \\
\text { of } \\
\text { Patients }\end{array}$ & $\begin{array}{c}\text { Average } \\
\text { Duration } \\
\text { of Coma } \\
\end{array}$ \\
\hline $\begin{array}{l}\text { Short and medium acting. } \\
\text { Long acting } \quad . .\end{array}$ & III & $\begin{array}{r}25 \\
8\end{array}$ & $\begin{array}{l}19 \text { hours } \\
37 \text { " }\end{array}$ \\
\hline $\begin{array}{l}\text { Short and medium acting } \\
\text { Long acting }\end{array}$ & $\begin{array}{l}\text { IV } \\
\text { IV }\end{array}$ & $\begin{array}{r}10 \\
4\end{array}$ & $24 \%$ \\
\hline
\end{tabular}
pital in $\mathbf{4 7}$ consecutive episodes of gross overdosage as judged by clinical criteria.

The short- and medium-acting barbiturates were pentobarbitone, quinalbarbitone, butobarbitone, amylobarbitone, and cyclobarbitone. The long-acting barbiturates were phenobarbitone or barbitone. Coma due to overdosage with long-acting barbiturates is significantly longer $(P<0.05)$ than that produced by short- and medium-acting forms.

These comments must not detract from Dr. McQueen's important plea that barbiturates should be avoided and safe hypnotics used if drugs are required for insomnia. We recently confirmed that nitrazepam is efficien as a hypnotic and yet safe in overdosage. ${ }^{2}-$ We are, etc.

N. WRIGHT. JoHN A. RAEbURN.

Regional Poisoning Treatment Centre, Royal Infirmary,
Edinburgh.

\section{REFERENCES} Matthew, H., and Lawson, A. A. H., Treatment
of Common Acute Poisonings, Edinburgh, Livingstone, 1967.

Matthew, H., Proudfoot, A. T., Aitken, R. C. B. Raeburn, J. A., and Wright, N., British Medica

\section{Automation in Pathology}

SIR,-Your leading article on automation in pathology (16 August, p. 374) reminds me of a problem that is of even greater interest to the clinician. It has recently been the subject of a correspondence in your contemporary the Lancet (12 July, p. 106). Whether the results of investigations are arrived at by a computer or by a technician, or the consultant pathologist himself, the problem for the clinician is the delays before the report is in his hands.

A consultant colleague, who had the great advantage of many years' experience as a general practitioner, once remarked, "Better the scruffiest bit of paper with the patien than the most beautiful report three months later." He was referring to letters about discharge of patients, but the same applies to reports of investigations.

If the necessary research effort were available, perhaps Britain could give a lead in the development of a system which would put the clinician in possession of such reports within hours rather than days.-I am, etc.,

London $\mathbf{W . 1}$

Robert Niven.

\section{Cigarette Advertisements}

SIR,-The New York Times ${ }^{1}$ is now to follow the lead of the Listener and apply strictures upon cigarette advertisements. These overdue precedents remind one of just how extraordinary it is that anything causing 50,000 deaths a year can still be advertised to the general public. One is simultaneously reminded of the situation which obtained in your own distinguished columns over a decade ago. ${ }^{2}$ Incidentally, may we be reassured on this point, please ?-I am, etc.

\section{J. P. Anderson.}

\section{Chest Unit,}

Cheddon Road Hoopital

Taunton, Somerset.

\section{REPBRBNCBS}

1 The Times, Saturday, 30 August.

Anderson, J. P., British Medical fournal, 1957, 1

* The B.M.f. ceased carrying advertisements for tobacco products in 1962.-ED. B.M.F.

\section{Plight of Long-stay Hospitals}

SIR,-I am sorry that Dr. J. T. R. Bavin (23 August, p. 470) has drawn the wrong conclusions from my letter (9 August, p. 361), written on behalf of the Clwyd and Deeside Group Medical Advisory Committee, concerning the diversion of funds to long-stay hospitals. His assumption that my committee consists entirely of general hospital staff is also inaccurate, since we have three long-stay hospitals in this group and approximately one-fifth of the members of my committee are doctors who are responsible for the care of long-stay patients.

It was not our intention, as Dr. Bavin suggests, to imply that subnormality and other long-stay hospitals should wait a further period while politicians find more money to rectify their long-standing problems. Nor did we express the belief that the needs of general hospitals should take priority over those of long-stay hospitals.

We recognize the need for a considerable amount of money to be spent urgently on the hitherto neglected long-stay hospitals. Our purpose was to sound a warning of the adverse effect that it would have on the hospital service generally if the necessary im- 